\title{
Feminist struggle over urban safety \\ and the politics of space
}

\begin{abstract}
This article explores safety and politics of space in two ways. First, it reviews research on women's fear and calls for safer cities, identifying four contradictions in the geography of fear discourse. Second, it elaborates on how including various forms of fear may repoliticize the contemporary depoliticized and co-opted safety discussion by focusing on sexist and racist threats rather than exclusively on the white middle classes. Here, threats to veiled Muslim women and their experiences in public spaces are, in particular, emphasised as exemplifying fears that are neglected in the safety debate. The article concludes that, rather than the whole safety issue being dismissed as 'neoliberal', there is an urgent need to strengthen the analysis of power and illuminate experiences of pain and fear in sexist and racist violence.
\end{abstract}

Key words: safety, fear, (Muslim) women, neoliberal urban development, racism

For over 100 years, feminist movements have been claiming space and asserting rights through both strategic action and everyday practices. In various ways, public and private, space are being negotiated. For example, feminist groups have organized marches in Western cities to 'take back the night' in protest against sexual threats in public spaces since the 1970s. Inspired by the radical feminist Andrea Dworkin, the first march was initiated in 1978 in the 
US, and such marches are still being organized. These demonstrations have been propelled onto a global scale: women are protesting against sexual violence around the world, most recently — and conspicuously — in India. There is no decline in these confrontations and their political implications. In Malmö, Sweden, after the annual 'Eighth of March’ demonstration in 2014, a group of feminists were attacked by Nazis and at least two people were seriously injured.

Such demonstrations and manifestations are a clear attempt to claim space and assert a right to the city. Meanwhile, in a Western neoliberal context, safety and freedom from violence are becoming a commodity, since issues of fear and safety have been co-opted by the authorities, property companies and other stakeholders. As a result, there has been an increasing focus on control, surveillance and security within a 'safety discourse' that dominates planning and urban renewal. Women and their fear of sexual violence are used as an argument for urban renewal projects. In such contexts the notion of 'women' is often limited to white middleclass women living in urban areas, excluding the fear of violence experienced by women outside this privileged category.

Safety debates in the social sciences have largely focused on western women although women elsewhere in the world, especially in occupied areas or war-torn territories, are more exposed to violence. An expert poll listing the most dangerous parts of the world for women ranks Afghanistan, the two Congo nations (Democratic Republic of the Congo and Republic of the Congo) and Pakistan as the world's most dangerous countries for women, owing to the barrage of threats ranging from violence and rape to dismal health care. ${ }^{i}$ Research in the past few decades shows that the extent of violence against women has increased and offers a global overview of the magnitude of the problem (Watts and Zimmerman, 2002). Similarities 
and differences in how fear and safety are experienced around the world and comparisons of the geographical contexts of North and South are relevant to illuminate (Peake and Rieker, 2013). However, this article primarily focuses on debates about the western social, political and economic context. The aim is to repoliticize the understanding of gendered spaces in a Western neoliberal urban situation.

Safety issues and the politics of Western space are approached from an everyday life perspective, first by looking back at research on women's fear and calls for safer cities, and reflecting on some internal contradictions. These contradictions revolve around the difficulties of pointing out women's vulnerable position without reinforcing stereotypes and existing social and spatial power relations. They are set out as a background to my argument about depoliticization. Second, the article illustrates the shift in women's safety debates from radical feminism to a contemporary depoliticized and co-opted safety discourse. This is followed by an attempt to take the discussion further by elaborating on how including various experiences of fear may repoliticize and enrich contemporary discussions focused mainly on protecting the white middle classes.

The argument of the article is that, rather than dismissing the whole safety debate as neoliberal and thereby disregarding its radical roots and background, we need to address the urgent need to modify it by taking into account fears that are excluded, unseen or unrecognized. This impetus for new theoretical framing of problems and arguments is based on the idea of radical equality and the need to act politically in public space, as put forward by Lynn Staeheli and Jacques Rancière, for example. This process includes both silent and hitherto invisible experiences of the spatial politics of everyday life and the spectacular marches. Particular attention is paid to the gendered and racialized forms of violence 
confronting Muslim women living in the West and wear veils. Feminism is about raising voices, but also listening carefully. The aim of the article is therefore to reinvent the safety discourse, making it more inclusive, by addressing the lives of women whose suffering from fear and threats in their everyday use of public spaces is often unrecognized and unobserved.

\section{From exposing women's fear of sexual violence...}

In the early 1980s Toronto enhanced its status by focusing on urban safety from a gender perspective. A committed women's movement, including academics, put the issue of fear of sexual violence on the political agenda. In the aftermath of the killing of 14 female engineering students in Montreal in $1989^{\mathrm{ii}}$, a debate arose on the lack of gender perspective in contemporary crime prevention. This galvanized the safety work already initiated, further boosting public support (Whitzman, 1992). The Toronto approach was broad; it included, for example, urban design, transport systems, public spaces, domestic violence and education programmes for the police. It also included new methods of learning about experiences of public spaces and how to develop participation in planning processes. Safety audits, an example of a grassroots-based planning tool, were introduced (Wekerle and Whitzman, 1995). Overall, safety issues acquired a local political status by becoming a marketing tool for the City of Toronto.

Initially, the ideas of empowering women and sounding out the most vulnerable groups dominated safety efforts, and the researchers involved were experienced in community development work. As part of the strategy, in the run-up to elections the women's group organized hearings where, for example, sexual violence was discussed with politicians 
(Whitzman, 1992). This ambitious and strategic work was undoubtedly based on an understanding of gendered power relations. These initiatives and this strategic approach were spread around the world as inspiration for other women's groups working on safety. The specific proposals made in Toronto were emulated by feminist planners and the ideas incorporated into safety checklists, not least in Sweden (Listerborn, 2000, 2002).

However, the focus on design and the built environment was also criticized for unduly emphasizing the scope for 'designing out fear' and thereby ignoring the underlying power relations (Koskela and Pain, 2000). Fear and safety research was also criticized for potentially confirming gender stereotypes and not stressing the complexity of social categories enough (Pain, 2001). Instead of describing women as fearful, Hille Koskela (1997) pointed to the social construction of fear, with the result that the boldness of women who did walk alone at night in the city was defined as a risky behaviour. This criticism draws on the work by Elizabeth Wilson, whose book The Sphinx in the City (1992) condemned much feminist writing as 'hostile to the city', and further argued that 'recent feminist contributions to the discussion of urban problems have tended to restrict themselves narrowly to issues of safety, welfare and protection’ (Wilson, 1992:10). Instead, feminists and others should recognize: 'women's right to the carnival, intensity and even the risks of the city. Surely it is possible to be both pro-cities and pro-women, to hold in balance an awareness of both the pleasures and the dangers that the city offers women, and to judge that, in the end, urban life, however fraught with difficulty, has emancipated women more than rural life or suburban domesticity’ (Wilson, 1992:10).

Putting the historical record straight by clarifying the role of women as agents in the production of space is important (see Hayden, 1982; Spain, 2001). At the same time, the 
geography of fear has ensured a theoretical contribution that brings power relations to bear in studying the uses of public spaces (Valentine, 1989, 1993; Pain, 1991). A balanced representation of women as victims and as active producers of and participants in public urban life is complex. While nobody today wants to reinforce the image of women as 'weak', most surveys still show women and immigrants to be the most vulnerable and fearful social categories in public spaces (NTU, 2009). These groups also tend to adjust their life and mobility in order to deal with a perceived risk of violence in the public sphere. There is therefore a need to note both aspects of a gendered and racialized urban life: freedom and restriction.

Most violence against women is perpetrated in a domestic setting. This leads to another dichotomy that this field of research often risks reinforcing: between the public and private spheres. Although the aim has been to illustrate fear in public spaces, the focus on the public sphere tends to marginalize the problem of fear in the private sphere. The home seems to be the only safe place to be. On an individual level, however, fear (and abuse) in the private sphere is very likely to reinforce fear in the public (Pain, 2001). Furthermore, defining private spaces as 'family-oriented' often ignores the fact that private space is also an arena of political debates and mobilization. In feminist theory this divide has been contested from various angles. Carol Pateman argues that feminist critique of the dichotomy between public and private 'is central to almost two centuries of feminist writing and political struggle; it is, ultimately, what the feminist movement is about' (1989: 118). Black feminists, in particular, have pinpointed the home as a site of mobilization and women's role in the civil rights movements (hooks, 1981). Although the feminist critique has developed an understanding of space as fluid and relational, the geography of fear tends to reinforce the spatial divide, or at least risks doing so. 
The feminist focus on women's fear has been complemented by research on interlocking systems of race, class, age and gender (Pain, 2001; Day, 1999). The notion of 'racialized fear', in particular, introduces a spatial dimension since what often appear to be local expressions of violence are intertwined with broader socio-spatial and political and economic patterns. In these 'glocal' (Listerborn, 2013; Brenner, 1998) expressions, for example, the Muslim female body in Sweden is associated with similar violent expressions in other parts of Europe, as well as with a global geopolitical perception of Muslim bodies as fearsome (Pain and Smith, 2008, Listerborn, 2015). The literature on gendered fear mentioned here often focuses on local experiences, while the literature on global conflicts and fear illustrates aspects of governance, legitimizing national and international actions to combat terrorism, enhance security or restrict immigration (Pain and Smith, 2008:4). This literature illustrates the structures and systems of fear and violence, but often neglects their emotional and experiential aspects.

An understanding of gendered and racialized spatial relations is useful to the geography of fear through its inclusion of violence in a national and geopolitical context. In this context, experience of pain and acts of racist violence against Muslim women wearing the hijab were explored in a 2008/2009 case study in Malmö. The results of this study show that where and how the violence occurs deviate from the established notion of urban violence and unsafety in the planning safety discourse. Stories of violent encounters in public spaces from the perspective of veiled Muslim women reveal surprising perpetrators. Most commonly, the women related, those who offended them publicly would be older, white Swedish women. Furthermore, the spaces and places mentioned as 'no-go areas' differed sharply from what are commonly understood as dangerous areas. To veiled Muslim women in Sweden, affluent 
suburban areas and inner-city (gentrified) neighbourhoods appeared hostile (see Listerborn 2015). These perceptions deviate from the media images of violent young immigrant men and violent neighbourhoods that were the focus of most safety projects. Some of the veiled Muslim women who had been subjected to violent acts and harassment felt that the society around them regarded them as dangerous and as potential terrorists.

Altogether, there seem to be several inherent contradictions within the dominant discourses on geography of fear: 1) regarding women's fear, there is a risk of hierarchical gender relationships being reproduced; 2) in terms of problems in the physical environment, there is a risk of social power relations being ignored; 3) the focus is on public spaces, while most gendered violence occurs in the private sphere; and 4) while some groups in society are empowered, other groups risk being further stigmatized and other experiences of fear tend to be ignored, especially in a 'localist' perspective. Furthermore, what people fear tends to shift over time, in relation to media discourses but also to (glocal) political and economic challenges. As in the example illustrated by the Muslim women, the violent acts they experience in everyday life must be understood in the global geopolitical context in the aftermath of 11 September 2001, as well as in the Swedish national(ist) context of opposition to immigration, alongside the particular local, urban context.

\section{... to the commodification of safety}

Inspired by the work of Toronto feminists that had inspired Swedish debates, I visited Canada in 2000 to meet the feminists and politicians who had been engaged in developing the strategies and literature on safety and attend municipal meetings. The results of the safety work were evident in the urban design and transport system, but the women’s group 
representatives were dissatisfied. The new municipal government had cut its budget for work against sexual violence, reduced the women’s groups' influence over safety work and developed a parallel strategy focusing on traditional situational crime prevention and a 'hardtarget’ approach (Listerborn 2002). Safety work, which may appear to be a neutral issue, seemed to have become highly political. Embedded in the new political and economic programmes, the gender aspects had become merely cosmetic. In the following year, security was strengthened in most Western countries. Gerda Wekerle, one initiator of the safety work in Toronto, confirms that in the aftermath of the World Trade Center attacks and in the context of the 'war on terrorism', 'the local level, the focus on community crime prevention in urban areas that emerged in the 1990s /.../ has also been appropriated for the antiterrorism project' (Wekerle and Jackson, 2005:43). The war on terrorism, and also military urbanism (Graham, 2009), fitted into the already emerging 'revanchist city'iii (Smith, 1996). So, what happened to the successful safety work in Toronto?

With reference to a wave of condominium development in Toronto in the mid-1990s that lasted until 2008, Leslie Kearn and Beverly Mullings (2013) describe its effects on urbanity from a gender perspective. Based on the global all-encompassing idea of inevitable progress towards a culture- and knowledge-based economy, the City of Toronto sought to boost urban density through high-rise buildings and investment in 'disinvested' areas to include them in 'better' use. Condominiums were ‘aggressively marketed towards women, particularly young and single women' (Kearn and Mullings, 2013:32), framed within a discourse of women’s liberation and urban space as affording emancipation for women. Borrowing the rhetoric from earlier feminist work, property companies earned new credentials while simultaneously contributing to the displacement of marginalized groups from various city zones to the 
periphery. Kearn and Mullings (2013:33) ask: 'Was gender a constitutive element of neoliberal urban restructuring in this case?'

The new condominiums paid attention to safety aspects. Some of the new buildings were located in low-income neighbourhoods with bad reputations. Their locations were presented as part of the attractive financial investment deals, with the argument that these flats would increase in value over the years, and of new buildings, with the presence of marginalized people providing a sense of urban authenticity. Most of the women interviewed in this case study did not complain about fear, and had developed coping strategies. For these women, fear and danger were mitigated by private security mechanisms and potential wealth accumulation. For the property companies, 'the extensive marketing of security features is not simply a way to attract women buyers; it is also a way for developers to colonise areas of the city that would have been deemed too risky for such investment because of social stigma and fear of crime’ (Kearn and Mullings 2013: 33). The women’s financial independence and enjoyment of the urban spectacle hide the 'pressing concern of inequality, poverty and marginality’ (Kearn and Mullings 2013: 34) well. Low-income women, single mothers, recent immigrants and people with disabilities do not belong to this group of young and mobile urban professionals. Comparable investments in transit, services and safety are not made in the districts where the marginalized people live. Clearly, the starting point of vulnerable groups' needs, as the women's groups stressed in the 1980s, has been interpreted by the market as gender-specific only, but other aspects of social power relations — class, race and immigration status — have been ignored. For the market, safety must be profitable; otherwise it is of no use. 
The case of Toronto tallies well with developments elsewhere. In Sweden, Business Improvement Districts (BIDs) based on safety surveys have been introduced. Urban regeneration plans have usually referred to crime statistics, and safety surveys have been carried out as a strategy to initiate processes of gentrification and displacement (Thörn and Holgersson, 2014; Baeten and Listerborn, 2015). At the same time, as criminologists point out, poverty-stricken residents of marginalized neighbourhoods are both more exposed to crime and experience more fear in their everyday lives (Estrada and Nilsson, 2011) than others. In addition, social movements and urban activists working against violence and fear are themselves subjected to violence and fear (Wekerle and Jackson, 2005). When pronounced inequality is based on gender, race or religion, activists are often subjected to violent threats from antagonists. In Sweden several cases of violent attacks on anti-racist and feminist activists by neo-Nazis illustrate this exposure risk, while also highlighting social exclusion and inequalities.

The underlying power relations of fear identified by feminists in the early 1980s are obviously still relevant. What has changed is that the idea of safety and security has entered the urban development market and become a central selling point, not least concerning women as a target group. But can feminists be blamed for this — for putting the issue of gendered fear on the agenda? And, since the safety debate has been blatantly co-opted by the market, should feminists merely dismiss it?

I argue that pinpointing unequal spatial distribution of fear and sexist and racist violence can be part of an overall notion of the right to the city and radical equality. But it is important to point out both the gendered and the racialist nature of urban dynamics, as well as their 
intersections. Thus, the safety debate and safety measures that prevail today need to be reimprinted with feminist and anti-racist politics.

\section{Is repoliticizing the safety issue possible?}

Today, safety issues are included in planning documents and women's fear of violence is recognized by the market and planners, as well as politicians from all political corners, in many western countries. Safety is deeply embedded in a planning tradition, as Leonie Sandercock argues: 'planning and urban management discourses are, and always have been, saturated with fear. The history of planning could be rewritten as the attempt to manage fear in the city’ (2003:108). Existing fear and safety discussions, however, seem trapped in a neoliberal and securitization frame, offering no radical solution to the sexual and racist violence that is apparently as daunting a problem as 30 years ago, or perhaps even more prevalent today. Violent attacks on women, feminists and anti-racist activists are common news in the West, at the same time as plenty of safety-driven urban regeneration plans are being developed. Regeneration plans based on crime and safety statistics do not, however, offer any solutions to the fear experienced by non-white and non-middle-class groups.

In the process of urban regeneration, from a socially sustainable perspective, the moment of actual ‘problem formulation' tends to be ignored. This could be interpreted in two ways. Either everybody agrees that safety is vital component of a well-functioning city but nobody appears to know how to achieve such an outcome through planning or other social processes, or the main purpose has never been to create safety for vulnerable groups, but rather to increase the market value of land and property. In both cases, there seems to be a need for a change in the theoretical framing of the problem, as well as in the practices of public safety 
interventions. By going back to the earlier debate, I want to stress the analysis of power relations as a primary entry point to the issues of fear and safety (Valentine, 1989), but also learn from the critique that the strong focus on gender, or rather women, and the (public) built environment may have been a mistake since it lent itself to an apolitical strand of research and practice in planning and architecture. This is especially so when 'women' is taken to mean only white, middle-class and upwardly mobile women.

Obviously, gender is perceived and performed in various ways, depending on where the gendered subject is situated in relation to other social categories. What may be described as some women's increased independence in certain (neoliberal) public spaces may lead to other women's increased exposure to fear and violence elsewhere. These relations are important to illuminate when fear and violence are discussed, to see what is actually negotiated and at stake, and to reveal how gender is used to create differences among women. As illustrated by the earlier examples from Sweden and Toronto, the notion of 'women' is often limited to white middle-class women living in urban areas, while the fear of violence experienced by women outside this group is excluded. The above-mentioned experiences of pain and acts of racist violence against Muslim women wearing the hijab are not included. Their experiences of public space and spatial politics do not fit into the contemporary safety discourse and are therefore not visible.

To repoliticize the safety discourse, another theoretical approach is needed that moves away from theories and strategies that are currently dominant and based on simplistic assumptions, such as the need for crowded streets to make the urban more vibrant and safer (Gehl et al., 2006) or such measures of crime prevention as 'fixing broken windows'. 


\section{Spatial politics and radical equality}

The last part of this article will focus on how we might theoretically address the problem of how gendered and racialized bodies — here, those of veiled Muslim women — claim space or just take up space in public through everyday activities and how, with such an approach, we might help to emphasize the political aspects of safety measures. Hille Koskela (1999) argued that women not only passively experience space, but also produce and reclaim it. This, she pointed out, happens not least through routinized use of space in order to 'tame' it by various expressions of courage and to develop, through these strategies, a 'spatial expertise'. These practices of resistance are based on everyday mobility, and the presence of women in public encourages other women to claim space. Similarly, Lynn A. Staeheli (2010) argues that bodies, sometimes unintentionally, perform political acts simply by being present in public spaces. This understanding of the politics of space implies a focus not only on elaborate and articulate political interventions, but also on the inclusion of less visible activities that also contribute to changes of political orders in public. This, of course, introduces the question of what is understood as political. What may be understood as political actions or political agency? I shall elaborate on my use of the term, inspired by philosopher Jacques Rancière’s understanding of the political and by the work of feminist scholars such as Lynn Staeheli.

Rancière urges people to think about equality as a starting point, rather than a goal, when he refers to the idea of 'radical equality'. A democracy demands equality: a radical equality in which everyone is equal to everyone else at any time (Rancière 2003). One has the right to be regarded as equal, not as different. We are all equal and should be treated in line with this understanding. What may sound obvious has political implications, such as which actions are 
defined as political. Resisting the 'given-ness' or allocation of place is thus a political concern.

Rancière's understanding of politics and space does not follow conventional lines of defining politics within political science, Instead, he draws on a philosophical tradition. To understand politics, he begins by defining the polis. This Greek word, meaning 'city-state' is construed as the seemingly natural government and organization, or order of things. In a non-pejorative sense, this is the product of a particular regime. The polis [Eng: police], however, is not identical to the state apparatus: it should be understood in broader terms, such as the distribution of places, names and functions. Political orders are not closed, but rather contested and full of tensions: ' . . the essence of the police is not repression but distribution — distribution of places, people, names, functions, authorities, activities, and so on — and the normalization of this distribution’ (Dikeç 2007:19). Politics, then, happens when the principle of distribution of spaces is contested, challenged or disturbed. Politics 'acts on the police' and 'puts into question the very distribution of the police, its partitioned spaces, which are normalized by regimes of governance' (Dikeç 2007:21). Political subjects appear in these spaces, even if they may not always themselves regard them as political. But in a long-term perspective, they can enhance a new order of things.

To Rancière not everything is political, only what breaks the order and challenges the distribution of places:

'Politics is not the exercise of power. Politics ought to be defined on its own terms, as a mode of acting put into practice by a specific kind of subject and deriving from a particular form of reason. It is the political relationship that allows one to think the possibility of a political subject(ivity), not the other way around'(Rancière 2001:1). 
The disturbances of spatial orders provoke resistance, sometimes from other citizens, and at other times from the authorities. Most importantly, it does not comply with the dominant order — as we see today in urban planning or compliance with the contemporary neoliberal order and co-option into it.

In Sweden a few violent events recently received publicity. In April 2011, a story from the small town of Tomelilla was told. A Muslim woman migrant from Somalia and her six-yearold daughter were repeatedly attacked with stones and racist slurs on their way to and from the local school. The mother was hit with stones three times and the daughter was hit once in the back. After a year of harassment the school nurse, encouraged by the school principal, helped the woman to report the incidents to the police, only to find out a week later that the case had been closed by the police for lack of evidence. No one from the police had talked to the woman who had been attacked. ${ }^{\text {iv }}$ Another story, from August 2013, was about a pregnant Muslim woman wearing a veil who was attacked in the suburb of Farsta in Greater Stockholm. The men attacking the woman pulled off her veil and pounded her head into a car so that she fainted. The brutality of the event brought an immediate public response. ${ }^{\mathrm{v}}$

Both events resulted in a nationwide public debate and demonstrations at various places, making these usually invisible and everyday racist attacks visible for a while.

These violent attacks in public spaces are involved in a set of spatial politics and spatial negotiations. The violent racist attacks are based on hatred of Muslim women, and this hate produces places and spatial orders attached to certain signs and bodies, in this case the veiled body (Listerborn 2015). The Muslim women in these events are forced to embody a particular 
identity by and for the perpetrator of the crime; and their bodies, hated as they are, become part of a spatial 'reorganization', categorized as a particular group or 'serial collectivity' (Young, 1994) through the symbolic function of the veil. Young uses the concept of 'serial collectivity’ to illustrate how a diverse social category, such as (Muslim) women (in this case), can form a group, internally or externally, when the context or situation demands it. Without claiming a definition, or a given identity, of what it means to be a (Muslim) woman, the group still acknowledges that individuals exist within structures that constrain and shape their actions. Externally, the Muslim women with veils are formed a group on the basis of religion, immigration, gender, and racist and sexist aggressions. Internally, they may form a group when the threat of violence becomes a common experience. However, their individual identity may shift over time and space, and between political contexts.

The hate that drives the violent perpetrators needs evidence of antagonism (Ahmed 2001), and the veil symbolizes multiple (imaginings of) differences: gender inequality, lack of integration, threat to Western ideals, terrorism, etc. The stereotypes of difference need repetition to be reproduced, as their origins are constructed. Thus, hate produces public spaces, places and spatial orders through certain signs and bodies. The violent encounters are, accordingly, part of a violent negotiation within a sociospatial hegemony.

A central aspect of this hegemony is based on nationalism, but also acted out, depending on local political contexts (Listerborn, 2015; Hancock, 2014). The national, the urban and the spatial political contexts are all orders that are being disturbed, but they are also decisive: in them, incidents are made visible or invisible. It is also in the national context that the contradictions and conflicts between gender and religion/ethnicity are played out (Hancock, 2014). Bringing in the visible and non-visible spatial politics and spatial negotiations that are 
carried on in urban public spaces may strengthen the prospects of the hitherto invisible subjects becoming political subjects in urban public space.

\section{From victim of fear to political subject}

Feminist movements have been struggling with issues of global solidarity and power relations between white women and women of colour since at least the late 1970s. Safety issues and combatting violence against women, however, have sometimes served as unifying themes, as in the case of the Coalition for Women's Safety in Boston in 1979, which Winifred Breines recalls (Breines 2006). Although coalitions and collaborations was never without power hierarchies, within an increasingly neoliberal economy and culture the act of solidarity diminishes.

In mainstream planning ideology, public spaces are important as an arena for people to meet and encounter one another and, while segregation and exclusion processes are the reality of most cities. The 'geography of the veil' (Listerborn, 2015) is deeply intertwined with segregation processes, and the places assigned to excluded groups indicate that public spaces are not democratic per se. Public spaces are not equally accessible to all, as feminist research has revealed. Political space is limited if you have no place to speak from on your own terms. Public spaces are regulated through management, policing or design, but also by the ways in which citizens encounter one another and racist and gendered power relations are acted out on an everyday basis. The handling of fear and spatial restrictions amongst politicians and planners is not unproblematic, while political struggles for access to public spaces have been co-opted and reclaimed by urban regeneration programmes and security businesses. People’s fear are used for other purposes, such as gentrifying attractive parts of the city. Implementing 
policies to create Business Improvement Districts, i.e. 'cleaning up’ areas, simultaneously implements gentrification, control, regulation and supervision.

To understand what kinds of politics of space are played out, we need to understand the context. The fear that Muslim women experience is embedded in an Islamophobic context where fear and hatred of Islam and Muslims have increased since the war on terrorism, in the aftermath of 11 September 2001. The geopolitical context appears in urban relations in the West (see Wekerle and Jackson, 2005; Graham, 2009). Hatred of Muslim women is both racialized and gendered, as more women than men report Islamophobic hate crimes to the police. This could be interpreted in several different ways, but one important national context in Sweden is that gender equality is a strong idea within national identity. There are certain notions of what gender equality means. Muslim women are, in this context, situated in a contradictory position, frequently portrayed as subdued or vulnerable within 'their own' community, while at the same time repeatedly being victims to violent encounters in public spaces with members of the national majority community. On the one hand they are patronized and subjected to well-meant interventions intended to help them in their perceived passive position. On the other, they are declared — through various violent encounters — unwelcome in public spaces (Listerborn, 2015; see also Hancock, 2014).

If we go back to the idea of radical equality and the political, being excluded from important public spaces leads to being ignored as political subjects and voices. Furthermore, being associated with certain spaces — spaces regarded as problematic or less important — the voices are not regarded as important to listen to. 
Power is acted out by locating people in places where politics can or cannot be done, or by defining them as incapable of describing and identifying their own situation. To be allowed to formulate a problem or situation, you need to be accountable. Definitions of victimhood exclude power, and thus also accountability. Your political credibility is attached to your class, ethnicity and gender, and to where you speak from. The position and spatial location of a voice defines whether the person is regarded as able to conduct political work and to become a political subject, rather than just an object of political action (such as protection or control).

If we understand spatial politics as breaking orders, it is a political project both to claim space and thereby become a 'talking' part of urban life, and also to break spatial orders through everyday activities. Then it also becomes important for society at large to listen — and this listening, too, is a political project. Within feminist geography these orders have often been described as a form of confinement in space. Against constructions of private spaces and the domestic sphere, public space is portrayed as dangerous — where the male gaze, violence and abuse abound, and contribute to restriction of spaces available to women. These norms are connected to honour and respectability, which define what you as a woman can or cannot do. Fear, real or imagined, is something that circumscribes and defines women's access to public spaces. This works through both internal and external confinements, national and global ideologies and interventions, and local realities.

Today, safety is a commodity, and some people do feel safer in upgraded areas. However, it is not equally distributed along gender, class, ethnicity, religion or citizenship lines. Fear of eviction or increased marginalization in relation to gentrification processes is seldom included in debates. The use of safety in dominant neoliberal planning and urban renewal projects 
cannot be understood as anything but increasing inequalities and fear amongst the least privileged groups, commonly migrants, older women, single parents and young adults. At the same time, 'women', and women's fear of sexual violence, have become an argument for urban renewal projects, and gender is being used to create differences instead of working for a radical equality.

But rather than the whole safety issue being dismissed as neoliberal, there is an urgent need to illustrate fears that are excluded, invisible or unrecognized. Experience of pain and acts of racist violence against Muslim women wearing the hijab is mentioned in this article as one example. Their experiences of spatial politics do not fit into the contemporary safety discourse and are therefore not visible. However, listening to the voices of these women and their experiences of fear and violence needs to be included as a means to do politics. The 'silent' spatial politics of everyday life has to join the politics of spectacular marches, and to redefine what the fear consists of and who is subjected to which threats. These issues are far too important to be left to urban planning consultants and safety companies.

\section{References}

Ahmed S (2001) The Organisation of Hate. Law and Critique (12): 345-365.

Baeten G and Listerborn C (forthcoming 2015) Renewing Urban Renewal in Landskrona, Sweden: Pursuing Displacement through Housing Policies. Geografiska Annaler Series B: Human Geography. 
Brenner N (1998) Global cities, glocal states: Global city formation and state territorial restructuring in contemporary Europe. Review of International Political Economy 5, no. 1: 137.

Breines W (2006) The Trouble Between Us: An Uneasy History of White and Black Women in the Feminist Movement. Oxford University Press.

Day K (1999) Embassies and sanctuaries: women's experiences of race and fear in public space. Environment and Planning D, 17, pp. 307-328.

Dikeç M (2007) Badlands of the Republic: Space, Politics and Urban Policy. Oxford: WileyBlackwell.

Estrada F and Nilsson A (2011) Fattigdom, segregation och brott ('Poverty, segregation and crime'). In Alm et al. (Eds) Utanförskap ('Outsiderness'). Dialogos and Institute for Futures Studies, Stockholm.

Gehl J, Johansen, Kaefer L and Reigstad S (2006) Close Encounters with Buildings. Urban Design International, Vol. 11, 29-47. DOI: 10.1057/palgrave.udi.9000162.

Graham S. (2009) Cities as Battlespace: The New Military Urbanism. City: analysis of urban trends, culture, theory, policy, action, 13:4, 383-402, DOI: 10.1080/13604810903298425. 
Hancock C (2014) 'The Republic is lived with an uncovered face' (and a skirt): (un)dressing French citizens. Gender, Place and Culture: A Journal of Feminist Geography, DOI:10.1080/0966369X.2014.958061.

Hayden D (1982) The Grand Domestic Revolution: A History of Feminist Designs for American Homes, Neighborhoods, and Cities. MIT.

hooks b (1981) Ain’t I a Woman?: Black Women and Feminism, Pluto Classics.

Kearn L and Mullings B (2013) Urban Neoliberalism and Violence, in Peake L and Rieker M. (Eds) (2013) Rethinking Feminist Interventions into the Urban, Routledge.

Koskela H (1997) 'Bold walk and breakings’: women’s spatial confidence versus fear of violence, Gender, Place and Culture, 4, pp. 301-319.

Koskela H and Pain R (2000) Revisiting fear and place: women's fear of attack and the built environment, Geoforum Volume 31, Issue 2, pp. 269-280.

Listerborn C (2000) Om rätten att slippa skyddas. En studie av trygghetsskapande och brottsförebyggande projekt och kvinnors rädsla för att röra sig i stadens rum ('The right not to be protected: a study of safety creation and crime prevention projects and women's fear of moving in urban spaces’). Chalmers University of Technology, Gothenburg, licentiate thesis 2000:3 (A) ISSN 0349-3091. 
Listerborn C (2002) Trygg stad. Diskurser om kvinnors rädsla i forskning, policyutveckling och lokal praktik ('Safe city: discourses on women's fear in research, policy development and local practice’). Chalmers University of Technology, Gothenburg , academic thesis 2002:(A).

Listerborn C (2013) ‘Suburban women and the “glocalisation” of everyday lives: gender and glocalities in underprivileged areas in Sweden.' Gender, Place and Culture, Vol. 20 (3): 290312.

Listerborn C (2015) Geographies of the Veil: Violent Encounters in Urban Public Spaces in Malmö, Sweden, Social and Cultural Geography, Vol. 16 (1) pp. 95-115, DOI: 10.1080/14649365.2014.950690.

National Safety Survey (2009) (Nationell trygghetsundersökning, NTU), Swedish National Council for Crime Prevention, www.bra.se.

Pain Rachel (1991) 'Space, sexual violence and social control: integrating geographical and feminist analyses of women’s fear of crime’. Progress in Human Geography 15, 415-431.

Pain Rachel (2001) ‘Gender, Race, Age and Fear in the City’. In Urban Studies 2001 38: 899_ 913.

Pain R and Smith S (2008) Fear: Critical Geopolitical and Everyday Life. Aldershot: Ashgate. 
Pateman C (1989) 'Feminist Critiques of the Public/Private Dichotomy’. In The Disorder of Women. Democracy, Feminism and Political Theory, Cambridge (Polity Press), p. 118.

Peake L and Rieker M (Eds) (2013) Rethinking Feminist Interventions into the Urban. Routledge.

Rancière J (2001) Ten Theses on Politics. Theory and Event 5:3.

Rancière J (2003) Disagreement. Minnesota Press.

Sandercock L (2003) Mongrel Cities: Cosmopolis II. New York: Continuum.

Smith N (1996) New Urban Frontier: Gentrification and the Revanchist City. London:

Routledge.

Spain D (2001) How Women Saved the City. Minnesota Press.

Thörn C and H Holgersson (2014) Göteborg - den urbana frontlinjen och 'nya Kvillebäcken' ('Gothenburg: the urban front line and “new Kvillebäcken”’). In Thörn C and Holgersson H (Eds) Gentrifiering ('Gentrification '), Studentlitteratur, pp. 157-188.

Young Iris Marion (1994) Gender as Seriality. Thinking about women as a social collective. Signs 19(3):713-738.

Valentine G (1989) The geography of women’s fear. Area, 21, pp. 385-390. 
Valentine G (1993) (Hetero)sexing space: lesbian perceptions and experiences of everyday spaces. Environment and Planning D: Society and Space, 11, pp. 395-413.

Watts C and Zimmerman C (2002) Violence against women: global scope and magnitude. Lancet, 359 (9313), pp. 1232-1237.

Wekerle G R and Jackson P S B (2005) Urbanizing the security agenda: analysis of urban trends, culture, theory, policy, action. City: 9:1, 33-49, DOI:

10.1080/13604810500050228.

Wekerle G R and Whitzman C (1995) Safer Cities: Guidelines for Planning, Design and Management. Van Nostrand-Reinhold, New York.

Wilson E (1991) The Sphinx in the City: Urban Life, the Control of Disorder and Women. London, Virago Press.

Whitzman C (1992) Taking Back Planning: Promoting Women’s Safety in Public Places — the Toronto Experience. Journal of Architectural and Planning Research, vol. 9: 2, pp. 169179.

Whitzman C (2007) Stuck at the front door: gender, fear of crime and the challenge of creating safer space. Environment and Planning A 39(11) 2715-2732.

${ }^{\mathrm{i}}$ http://tribune.com.pk/story/189294/pakistan-ranks-3rd-on-list-of-most-dangerous-countries-for-women/ 4.3.2015. 
ii In the 'Montreal Massacre’ of 1989, 14 women died when a gunman, Marc Lépine, staged his attack at Montreal's École Polytechnique on 6 December. Armed with a rifle, he stormed into a classroom, separated the men from the women, and declared he hated feminists before opening fire on the women. The shooting sparked a national debate about gun control and violence against women. In 1991, Parliament declared 6 December the National Day of Action and Remembrance on Violence Against Women. (Source: http://www.cbc.ca/news/canada/montreal/montreal-massacre-events-mark-1989-shootings-1.791903).

'iii 'Revanchist city' is a term coined by Neil Smith in the 1990s to illustrate the similarities between the French 'revanchists' in late 19th-century Paris with the processes of gentrification and political climate of New York in late 20th century. The term captures the urban condition created by a political shift to an era of neoliberal revanchism characterised by a discourse of revenge against minorities, the working class, feminists, environmental activists, gays and lesbians, and recent immigrants. These groups were regarded as the 'public enemies' of the bourgeois political elite and their supporters, according to Smith.

iv Article in the daily paper Sydsvenska dagbladetDagbladet, http://www.sydsvenskan.se/sverige/stenen-iryggen-blev-droppen/ 04/088/04/ 2011. In August 2012 similar events occurred in Forserum, another small Swedish town, where citizens with Somali backgrounds told of violent incidents of abuse, stones being thrown at them and other incidents, resulting in large groups having movedmoving away from the village.

v See Expressen, http://www.expressen.se/nyheter/gravid-kvinna-fick-huvudet-dunkat-i-bil/ 17/08/2013. After the attack a national petition against violent acts towards women wearing veils was arranged, and the petition featured on BBC News, USA Today and Al-Jazeera. See http://www.expressen.se/nyheter/hijabuppropet-spridsnu-over-hela-varlden/ 20/08/2013. 